task of the department of physical culture in the aspect of development of mass student sports is formed. The rules which should be followed by occupations of physical culture and improving and sports activity are considered. It is determined that one of the priority directions in the development of higher education in the field of physical culture in the context of improvement is the humanization of its content. Measures have been developed to form an effective system of physical education, sports and health for student youth.

Key words: education, physical culture, physical education, physical culture and sports activities, sports, health.

\author{
UDC 378.147 \\ DOI https://doi.org/10.31392/NPU-nc.series5.2021.79.2.12
}

Polishchuk G. V.

\title{
THEORETICAL DEVELOPMENT AND PRACTICAL SIGNIFICANCE OF "BULLYING" CONFLICT RESOLUTION CASE FOR FUTURE FOREIGN LANGUAGE TEACHERS
}

The article proposes a theoretical basis for situated learning or case-study, which is becoming widespread in pedagogy with subsequent practical implementation in the educational process at the present stage of science and society development. It is determined that the use of case study allows the projection of teaching activities with its subsequent reproduction in the student's activities; algorithmization of the educational process; acquisition of optimal results regardless of the individual characteristics of teachers and students. The article proposes the interpretation of case study as modern pedagogical technology of its participants' interaction during the analysis and solution of a wide range of situational problems in various fields of knowledge. It is proved that case study develops analytical, communicative and organizational skills of future foreign language teachers. The main characteristics of the case are clarified. The algorithm of case work consisting of five stages is defined. "Bullying" conflict case is developed, aimed at analyzing and discussing the problems of overcoming and preventing bullying as a worldwide problem that can create negative lifelong consequences. It is also tested that the case has a significant impact on students 'professionalization, interest formation and positive motivation. The case conclusion in both the Ukrainian and foreign languages is substantiated, which contributes to the training of communication skills in a foreign language in the field of professional activity, detection of speech independence, practical implementation of communication skills, etc. It is proved that professional problem cases, namely those related to the prevention and overcoming of such negative social and psychological-pedagogical phenomena as bullying, will allow organizing coordinated work of school, teachers and family to create psychological comfort for bullying victims to gain a positive experience of support and trust, as well as significantly reduce the level of aggression and promote the formation of tolerance, empathy in students to implement secondary prevention of bullying.

Key words: case study, algorithm, problem case, bullying, bullying prevention, consequences.

(статтю подано мовою орихіналу)

The contemporary stage of the development of pedagogical science is characterized by the keen interest of the scholars to the technological approach to the process of organization of learning activities in high educational establishments which means effective transference of educational process to the new optimal level of high results and intensity. Intellectual discourse as for the essence of the notion "innovative pedagogical technology" (in this paper we use the definition of "innovative pedagogical technology" given by L. Sushentseva as well-disposed system of procedures, actions, operations allowing to reach predicted and diagnostically foretell results in constantly changing conditions of educational process [10, p. 67]) in the XXI century proves intense interest in this phenomenon as it allows the projection of teaching activities with its subsequent reproduction in the student's activities; algorithmization of the educational process; acquisition of optimal results regardless of the individual characteristics of teachers and students.

Among contemporary innovative technologies case study has special significance in professional training of future foreign language teachers as is proved by its historical development and time approbation being widely used in different spheres of knowledge nowadays. For instance, case study has been in the focus of many research studies: K. Bagriy [1], I. Osadchenko [7], Ju. Surmin [9]; case study in the process of teaching foreign languages is drawn attention to by O. Belkina [2]; M. Kuimova, D. Evdokimov, K. Fedorov [5], Y. Laptinova [6], L. Pet'ko [12] and others. Thus, the overview of existing approaches to case study showed that is regarded in pedagogy as method, technology with pedagogical case as the didactic/teaching unit; the resolution of the case allows to create conventional model of professional activity [9, p. 19-20; 7, p. 13; 6, p. 102], so the article proposes the interpretation of case study as modern pedagogical technology of its participants' interaction during the analysis and solution of a wide range of situational problems in various fields of knowledge.

The aim of the article. Case study includes different forms and methods of the analysis and solution of a wide range of situational problems gaining special relevance in professional training of students in high educational 
establishments as it has a significant impact on students' professionalization, interest formation, positive motivation, tolerance, critical thinking, friendly relationships etc. It should be also underlined that case study is aimed to develop different skills of future specialists such as the ability to view the problems from the opponents' point of view, the ability to quick adaptation to group work and organize the discussion of the problem, to determine the level of one's competence, to make autonomous and responsible decisions and realize them, to come in contact with people, to exchange information defending one's point of view, to prevent clashes and misunderstandings, to be able to find the sources of conflicts and to come to reasonable decisions, to reach a compromise. As we see, case study develops analytical skills (analysis of different problems, making critical conclusions), communicative (productive discussions with opponents, protecting one's point of view) and organizational skills (making autonomous and responsible decisions, preventing clashes and misunderstandings) of future foreign language teachers.

Examination of the material provides evidence that certain difficulties the researcher comes across while developing pedagogical situations or problems taking into consideration the desired goal. The most important issue here as pointed out by scientists (G. Grebenkova, S. Ivanov, I. Fedulova, T. Mostenska and others) is the correspondence of the problem case to the following characteristics: it should have definite goal, concern actual and important problem, illustrate concrete life aspects, typical situations, be relevant as to the size and difficulty level, describe dramatic situation with adoption of critical decision, have variability of decisions, stimulate group work of the students, keep active interest of the students throughout the discussion and give the possibility to generalize the results and estimate the effectiveness of the group/team work, develop analytical thinking and practical skills.

Mentioned above characteristics were taken into consideration while "Bullying" conflict resolution case for future foreign language teachers was developed recognizing the potential health risk of bullying in schools, to prevent it from happening and to stop bullying from continuing once it has occurred. Thus, the following points were substantiated: the case is realistic but not complicated with details; it is connected with pedagogical conflictology and aimed at analyzing and discussing the problems of overcoming and preventing bullying as a worldwide problem that can create negative lifelong consequences. It is also tested that the case has a significant impact on students' professionalization, interest formation and positive motivation. The case conclusion in both the Ukrainian and foreign languages is substantiated, which contributes to the training of communication skills in a foreign language in the field of professional activity, detection of speech independence, practical implementation of communication skills, etc. Students had an opportunity to support each other while discussing the problem situation. It should be added that the real names of the participants have been changed; illustrative examples were taken from the Internet resources etc.

The following elements should be included into the structure of the case: the title, the description of the case, conflict participants, the purpose of the case, conflict situation/incident, diagnostic methods, and questions for group discussion, references, additional materials and tasks for self-study.

It is obvious that special attention was paid to the questions which were divided into those given to the students before the class and the questions to be discussed while analyzing conflict situation. What facts are presented in this case? What predictions are made in this case? What conclusions were made? Have you gained any life experience in the process of resolving the problem? What recommendations could be made for teachers, students, schoolchildren after this discussion? What kind of behavioral strategies can be implemented? What will be the outcome?

The algorithm of case work consisting of five stages is defined where the overview of existing approaches to the study are taken into consideration $[1 ; 4 ; 6]$.

The first stage (10-15 minutes depending on case difficulty) is the introduction of the problem where the topic and the aim are clarified, the case is presented where illustrations (movies, pictures etc.) are used and the stages of work are defined.

The second stage (15-20 minutes) includes the investigation and analysis of the situation by the students who can also question a teacher for additional information; search of the possible ways of conflict resolution using personal experience and professional knowledge.

The third stage (20-25 minutes) - group discussion where active personal participation and involvement are necessary, maintaining a balance between formality and informality. The teacher should be knowledgeable with the topic to give assistance. During the process of active discussion, the confrontation of different points of view may be witnessed, thus the teacher should control the audience, manage the time limit and generalize the suggestions of the students, make references to additional resource materials and stimulate creative activity of the students.

The fourth stage (10-15 minutes) involves case resolution strategies.

The fifth stage (5-10 minutes) is aimed at assessment of the students' decisions, participation, and the choice of the best conflict resolution strategy. As it turned out, this algorithm of case work duration runs for the whole class and gives the opportunity to activate educational process and teach students making autonomous and responsible decisions.

The last item to consider is the brief survey of "Bullying" conflict resolution case for future foreign language teachers.

Statistic data $[3 ; 8 ; 11 ; 13]$ : Bullying is one of the most significant school problems experienced by children and adolescents and affects approximately $30 \%$ of students in U.S. public schools. This included $13 \%$ as bullies, $10.6 \%$ as victims and $6.3 \%$ as bully-victims. Bullying has been defined as repeated exposure to negative events 
within the context of an imbalanced power relationship. Bullying is a serious public health problem that may include verbal or physical injury, as well as social isolation or exclusion. The overwhelming majority of respondents (approximately 1200 children) answering the questions of the Internet site Kids Poll recognized themselves as bullying victims (48\%), $42 \%$ recognized themselves as aggressors in school bullying assessing it mainly as psychological misunderstanding, incompatibility of interaction participants in the process of conflict, discordance in ideas about ways of conflict solution. According the investigation of the most prominent Norwegian psychologist Olweus, $11 \%$ of boys and $2.5 \%$ of girls in secondary school realize violence, initiate and play leading roles ("bullies" or persecutors, aggressors); USA National investigation proves that $29.9 \%$ of American schoolchildren were involved in the acts of violence, where $13 \%$ played the roles of aggressors. It was underlined that the majority of aggressors are schoolchildren of the 6-8 grades. At the same time, $74 \%$ of high-grade students prove the fact of bullying existence in their schools.

"Bullying" conflict resolution case: Case problem - falling out between two girls for boy's affection; Conflict participants: Julia and Roxy, girls, Nick, a boy and their classmates; The object - the relationships between children in the class; The aim - to discuss behavioral strategies helping to overcome bullying in school environment; Conflict situation - the girls cannot share the boy's affection; Incident: the girls belong to different social groups having different life values.

Diagnosis methods: 1) to differentiate the participants of the conflict; 2) to investigate the biography of the conflict (Julia has arrived from Lugansk region and is the pupil of the 8-F grade for a short period of time); 3 ) Roxy and Nick are her classmates, and it is important that Julia and Nick live in the same block of flats (Julia's parents rent a flat there; 4) clarification of the positions of the conflict participants: Roxy is in love with Nick, she is informal leader of the class, having economically prepared parents; it goes without saying; she dislikes Julia who is less cooperative, less sociable, poorly dressed girl, too excited, nervous due to the war stresses, with no leadership skills; she suffers from low self-esteem and low academic achievements, which are considered as risk factors for being victimized; on the contrary, Nick sympathizes with Julia, supports and helps her; Roxy is irritated by these situational factors; her bullying behavior was related to prestige in terms of popularity among her classmates; 5) the reasons of conflict: the peculiarities of Julia's behavior; the desire of Roxy not to lose Nick's sympathy; 6) the intensions of conflict parties: Roxy demonstrates her leadership qualities, on the contrary, Julia cannot adapt to new educational environment, Nick ignores Roxy and makes friends with Julia. Description of the situation. Julia lived in Lugansk with her family, but the war made them leave their apartment, more than that, the mine was closed and the family made ends meets. Her father's friend helped them to move to Kyiv where they rented a flat and had an opportunity to find new job. Julia was not welcomed by her classmates and Nick turned to be the only support for her helping to do the home assignments, defending her at school. Certainly, Roxy was very angry about it, she was responsible for psychological pressure and aggression of her classmates towards Julia. When Nick was ill, Roxy decided to meet Julia after classes and with a group of girls started physical humiliation over Julia. Her friends were making pictures on mobile phones.

Questions: What was the reason of the fighting? Who do you think is right? What is the main reason of children's cruelty? Is it possible to develop the culture of interrelations of schoolchildren, tolerance and mutual respect to people? What are the priority tasks in prophylaxis and overcoming of school bullying? What measures should be taken by teachers and school administration to prevent this disgusting phenomenon? What strategies have been implemented to improve classroom behavior?

Resolution: the intention of the students to work out bullying prevention program as the complex of consultative, organizational and corrective measures including training sessions with bullying victims, meetings with their parents, different forms of individual work with pupils etc.

Conclusions. To conclude we can state that conflict resolution skills of the students were practiced successfully also due to the illustrative material used: contemporary Ukrainian film "School" by O. Larionov, I. Litvinenko and others at the first stage of case work. Second stage was useful as the careful investigation of the situation where students (4 persons in the micro groups) discussed all details of school life situation. At the third stage they suggested their own variants of conflict resolution and persuaded the groupmates in the correctness of their propositions. Thus, several interesting ways were discussed at the fourth stage and at the closing session the results were estimated. At this stage the criteria of estimation of students' results were defined, the preparation for classes was taken into consideration (self-study exercises), active participation in case work, creative team work etc.

Generalizing the results, we should underline the theoretical and practical significance of "Bullying" conflict resolution case for future foreign language teachers, as it is proved that professional problem cases, namely those related to the prevention and overcoming of such negative social and psychological-pedagogical phenomena as bullying, will allow organizing coordinated work of school, teachers and family to create psychological comfort for bullying victims to gain a positive experience of support and trust, as well as significantly reduce the level of aggression and promote the formation of tolerance, empathy in students to implement secondary prevention of bullying as students will have the ability to manage stress and other life difficulties that can help boost confidence and selfempowerment, further promoting faith in yourself. It is undoubtedly a very interesting and promising field of investigation and much is expected from the researches in future as it is highlighted that implementation of case study develops analytical, communicative and organizational skills of future foreign language teachers and has a signifi- 
cant impact on students' professionalization, interest formation and positive motivation, contributes to the training of communication skills in a foreign language in the field of professional activity, detection of speech independence, practical implementation of communication skills, etc.

\section{Bibliography:}

1. Багрій К. Особливості застосування методу кейсів у процесі професійної підготовки майбутнього фахівця. Вісник Чернівецького торговельно-економічного інституту. Серія: Економічні науки. 2013. Вип. 4. С. 368-371. URL: http://nbuv.gov.ua/ UJRN/Vchtei 2013463

2. Белкина Е. Йпользование метода кейс-стадии при обучении студентов неязыковых направлений вуза иностранному языку. Филологические науки. Вопросы теории и практики. 2015. № 5 (47) : в 2 ч. Ч. І. С. 33-36.

3. Застосування діагностичних мінімумів в діяльності працівників психологічної служби : методичні рекомендації / авт.упор.: В. Горленко, В. Острова, Н. Сосновенко, І. Ткачук ; за заг. ред. В. Панка. Київ : УНМЦ практичної психології і соціальної роботи, 2018. $106 \mathrm{c}$.

4. Калаур С. Система професійної підготовки майбутніх фахівців соціальної сфери до розв'язання конфліктів у професійній діяльності : дис. ... докт. пед. наук : 13.00 .04 ; Тернопільський національний педагогічний університет ім. Володимира Гнатюка. Тернопіль, 2018. 676 с.

5. Куимова М., Евдокимов Д., Федоров К. Метод case-study при обучении иностранного языка студентов старших курсов неязыковых специальностей. Филологические науки. Вопросы теории и практики. 2013. № 3 (21). Ч. 1. С. 88-90.

6. Лаптінова Ю. Ситуаційна методика у формуванні іншомовної комунікативної компетентності майбутніх фахівців у галузі театрального мистецтва. Педагогічні науки. 2016. № 65. С. 102-107.

7. Осадченко I. Технологія ситуаційного навчання у підготовці майбутніх учителів початкової школи : автореф. дис. .... докт. пед. наук : 13.00.09 ; Інститут педагогіки НАПН України. Київ, 2013. 39 с.

8. Створення системи служб порозуміння для впровадження медіації за принципом "рівний - рівному/рівна - рівній” та вирішення конфліктів мирним шляхом у закладах освіти. Київ : ФОП Нічога С., 2018. 174 с.

9. Сурмін Ю. Кейс-метод: становлення та розвиток в Україні. Вісник Національної академї державного управління. 2015. № 2. C. 19-28.

10. Сушенцева Л. Інноваційні педагогічні технології у процесі підготовки майбутнього професійно мобільного педагога професійного навчання у вищому навчальному закладі (теоретичний аспект). Наукові записки Кіровоградського держсавного педагогічного університету імені Володимира Винниченка. Серія Проблеми методики фізико-математичної і технологічної освіти. 2016. Вип. 9 (3). С. 65-70. URL: http://nbuv.gov.ua/UJRN/nz_pmfm_2016_9(3)_19.

11. Цюман Т., Бойчук Н. Кодекс безпечного освітнього середовища : методичний посібник. Київ, 2018. 56 с.

12. Pet'ko L. "Case Study" Method as Means of Formation of a Professionally Oriented Foreign Language Teaching Environment in University Conditions. Intellectual Archive. Series "Education \& Pedagogy". 2015. Vol. 4. No. 4 (July). Toronto : Shiny World Corp. P. 48-65. [in Ukrainian]

13. Huddleston L.B., Varjas K., Meyers J., Cadenhead C. A Case Study with an Identified Bully: Policy and Practice Implications. West J Emerg Med. 2011 Jul. No. 12 (3). P. 316-323. [in English]

\section{References:}

1. Bahrii K. Osoblyvosti zastosuvannia metodu keisiv u protsesi profesiinoi pidhotovky maibutnoho fakhivtsia [Peculiarities of implementation of case study in professional training of future specialist]. Visnyk Chernivetskoho torhovelno-ekonomichnoho instytutu. Ser.: Ekonomichni nauky. 2013. Vyp. 4. S. 368-371. URL: http://nbuv.gov.ua/UJRN/Vchtei_2013_4_63. [in Ukrainian]

2. Belkina E. Ispolzovanie metoda keys-stadi pri obuchenii studentov neyazyikovyih napravleniy vuza inostrannomu yazyiku. [The usage of case study in teaching foreign languages the students of non-language specialities]. Filologicheskie nauki. Voprosyi teorii i praktiki. 2015. № 5 (47): v 2 ch. Ch. I. P. 33-36. [in Russian]

3. Zastosuvannia diahnostychnykh minimumiv $\mathrm{v}$ diialnosti pratsivnykiv psykholohichnoi sluzhby [Implementation of diagnostic minimum while diagnosing the workers of psychological aid]: [metod. rek.] / avt.-upor.: V. Horlenko, V. Ostrova, N. Sosnovenko, I. Tkachuk ; za zah. red. V. Panka. Kyiv: UNMTs praktychnoi psykholohii i sotsialnoi roboty, 2018. 106 s. [in Ukrainian]

4. Kalaur S. Systema profesiinoi pidhotovky maibutnikh fakhivtsiv sotsialnoi sfery do rozviazannia konfliktiv u profesiinii diialnosti [The system of professional training of future specialists of social sphere for conflict resolution in professional activity]: dys. ... dokt. ped. nauk: 13.00.04 / Ternopilskyi nats. ped. un-t im. Volodymyra Hnatiuka. Ternopil, 2018. 676 s. [in Ukrainian]

5. Kuimova M., Evdokimov D., Fedorov K. Metod case-study pri obuchenii inostrannogo yazyika studentov starshih kursov neyazyikovyih spetsialnostey [Case study method used to teach upper grade non-language students foreign languages]. Filologicheskie nauki. Voprosyi teorii i praktiki. 2013. № 3 (21). Ch. 1. S. 88-90. [in Russian]

6. Laptinova Yu. Sytuatsiina metodyka u formuvanni inshomovnoi komunikatyvnoi kompetentnosti maibutnikh fakhivtsiv u haluzi teatralnoho mystetstva [Situational method used to form foreign communicative competence for future specialists in theatrical art]. Pedahohichni nauky. 2016. № 65. S. 102-107. [in Ukrainian]

7. Osadchenko I. Tekhnolohiia sytuatsiinoho navchannia u pidhotovtsi maibutnikh uchyteliv pochatkovoi shkoly [Case study in training future elementary school teachers]: avtoref. dys. na zdob. nauk. stup. d-ra ped. nauk: 13.00.09 / In-t pedahohiky NAPN Ukrainy, Kyiv, 2013. 39 s. [in Ukrainian]

8. Stvorennia systemy sluzhb porozuminnia dlia vprovadzhennia mediatsii za pryntsypom "rivnyi - rivnomu/rivna - rivnii" ta vyrishennia konfliktiv myrnym shliakhom u zakladakh osvity [Creation of agreement service for implementation of mediation following the principle equal to equal and peaceful conflict resolution strategies in educational establishments]. Kyiv: FOP Nichoha S., 2018. 174 s. [in Ukrainian]

9. Surmin Yu. Keis-metod: stanovlennia ta rozvytok v Ukraini [Case-method: the beginning and development in Ukraine]. Visnyk Nats. akademii derzhavnoho upravlinnia. 2015. № 2. S. 19-28. [in Ukrainian]

10. Sushentseva L. Innovatsiini pedahohichni tekhnolohii u protsesi pidhotovky maibutnoho profesiino mobilnoho pedahoha profesiinoho navchannia u vyshchomu navchalnomu zakladi (teoretychnyi aspekt) [Innovative pedagogical technologies in training professionally mobile teacher of professional training in high educational establishment]. Naukovi zapysky [Kirovohradskoho derzhavnoho pedahohichnoho universytetu imeni Volodymyra Vynnychenka]. Ser.: Problemy metodyky fizyko-matematychnoi i tekhnolohichnoi osvity. 2016. Vyp.9 (3). S. 65-70. URL: http://nbuv.gov.ua/UJRN/nz_pmfm_2016_9(3)_19. [in Ukrainian] 
11. Tsiuman T., Boichuk N. Kodeks bezpechnoho osvitnoho seredovyshcha [Codex of safe educational environment]: metod. posib. Kyiv, 2018. 56 s. [in Ukrainian]

12. Pet'ko L. "Case Study" Method as Means of Formation of a Professionally Oriented Foreign Language Teaching Environment in University Conditions. Intellectual Archive. Series "Education \& Pedagogy”. 2015. Vol. 4. No. 4 (July). Toronto: Shiny World Corp. P. 48-65. [in Ukrainian]

13. Huddleston L.B., Varjas K., Meyers J., Cadenhead C. A Case Study with an Identified Bully: Policy and Practice Implications. West J Emerg Med. 2011 Jul; 12 (3): 316-323. [in English]

Поліщук Г. В. Теоретична розробка та практичне значення кейсу розв'язання конфлікту стосунків “Булінг” для майбутніх вчителів іноземних мов

У статті автором запропоновано теоретичне підгрунтя ситуаційного навчання або кейс-стадi (case-study), що на сучасному етапі розвитку науки та суспільства набуває поширення у педагогіиі з подальшою практичною імплементацією в освітній процес. Визначено, щзо використання ситуаційного навчання уможливлює проєктування викладацької діяльності з подальшим його відтворенням у діяльності студента; алгоритмізацію освітнього процесу; отримання оптимальних результатів незалежно від індивідуальних особливостей викладачів і студентів. У роботі запропоновано тлумачення ситуаційного навчання як сучасної педагогічної технології інтерактивної взаємодії ї̈ учасників у процесі аналізу й вирішення широкого спектру ситуаційних проблемних завдань у різних галузях знань. Доведено, щзо ситуаційне навчання розвиває в майбутніх учителів іноземних мов аналітичні вміння, комунікативні навички, організаційні вміння. 3'ясовано основні характеристики кейсу. Визначено алгоритм роботи над кейсом, що складається з п'яти етапів. Розроблено кейс конфлікту стосунків “Вullying”, спрямований на аналіз та обговорення проблем подолання й профілактики булінгу, а також доведено, щуо кейс має істотний вплив на професіоналізацію, формування інтересу та позитивної мотивачії студентів. Обтрунтовано укладання кейсу як українською, так i іноземною мовами, щь сприяло тренуванню навичок спілкування іноземною мовою у сфері професійної діяльності, виявленню мовленнєвої самостійності, практичній реалізащї комунікативних умінь $і$ навичок тощсо. Доведено, щзо проблемні кейси професійного спрямування, а саме ті, щзо стосуються попередження та подолання такого негативного соиіального й психолого-педагогічного явища, як булінг, дадуть змогу організувати скоординовану роботу школи, педагогів та родини у напрямі створення психологічного комфорту для отримання жертвами булінгу позитивного досвіду підтримки й довіри, а також істотно знизять рівень агресивності та сприятимуть формуванню толерантності, емпатї̈ в учнів задля вторинної профілактики виникнення булінгу.

Ключові слова: ситуаційне навчання, алгоритм, проблемний кейс, булінг, попередження та профілактика булінгу, наслідки. 